$\underset{\text { MaY } / \text { Ium }}{1095}$

Lee E. Ohanian is an assistant professor at the University of Pennsylvania. Alan C. Stockman is chairman of the Department of Economics at the University of Rochester, and serves os o consultonil to the Federal Reserve Bank of Riehmond and the Federal Reserve Bank of Cleveland.

\section{Theoretical Issues of Liquidity Effects}

\section{Lee E. Ohanian and Alan C. Stockman}

0 ne of the most pervasive real effects long-claimed for monetary policy is its ability to affect interest rates in the short run through channels other than the standardexpected inflation effect. The alleged shortterm inverse relationship between interest rates and monetary policy is often called the "liquidity effect" of monetary policy. We use the term liquidity effect to refer to the purported statistical relation between expansion of bank reserves or monetary aggregates (or perhaps only surprise expansions of these aggregates) and short-run reductions in short-term interest rates. The liquidity effect can also refer to the common interpretation of this purported statistical relation: that the same central bank action that changes bank reserves or monetary aggregates also changes short-term interest rates. This definition corresponds to early use of the term, for example, by Friedman in $1968 .^{1}$

We distinguish between a nominal liquidity effect (the aforementioned relation with a nominal interest rate) and a real liquidity effect (the aforementioned relation with a real interest rate). Either may occur without the other. For many purposes, real liquidity effects are more interesting because they indicate real effects of monetary policy. On the other hand, central banks around the world claim that their operating procedures directly target or control nominal interest rates-that they reduce reserves of the banking system (perhaps through open market sales) to raise the nominal interest rate or raise reserves of the banking system (perhaps through open market purchases) to reduce the nominal interest rate. It is difficult to interptet these claims without a coherent model of nominal liquidity effects.

The monetary policies that the Federal Reserve claims that it follows require the existence of liquidity effects. Many central bank operating procedures that involve use of the federal funds rate (or any other interest rate) as a target, instrument, or operating variable of monetary policy require a liquidity effect. The current operating procedure of the Federal Reserve is predicated on the existence of a liquidity effect in the sense that the Fed uses the federal funds rate as its proximate instrument of policy and contracts quantities of reserves and monetary aggregates by raising the funds rate (and vice versa). When the Fed raises the federal funds rate, it reduces reserves by the amount sufficient to achieve the desired increase. The smaller the required reduction in reserves, the larger the implied nominal liquidity effect. Of course, a central bank operating procedure that attempts only to tie down the nominal interest rate (which ties down the real interest rate plus the expected rate of change of the price level) may lack a nominal anchor to tie down the level of prices. If, however, the operating procedure also includes a provision to revert to control over the level of monetary aggregates if inflation exceeds some critical level, then the price level may be anchored at least within a certain range.

Attempts to isolate liquidity effects empirically are often subject to a unique problem: If the central bank operating procedure involves direct targeting of a short-term interest rate, statistical work and economic models that treat a monetary aggregate as exogenous and the nominal interest rate as endogenous may be misleading. This has led many economists to question the existence of liquidity effects. Although we do not attempt to resolve that issue in this article, we note that other kinds of evidence (that do not involve regressions of interest rates on allegedly exogenous monetary aggregates) suggest important liquidity effects in the

\footnotetext{
Some economists use the ferm differently, viz. to refer to a paticutor thiss of theorefitital models attemptiang to explain the purported reatrion.
} 
data. Cook and Hahn (1989), for example, interpret their results as showing that changes in Fed targets for the federal funds rate have large, immediate effects on three-month, sixmonth and 12-month Treasury bill rates, without any apparent reverse effects of Treasury bill rates on the funds rate.

This article assumes the existence of real and nominal liquidity effects in the data and discusses the main explanations for liquidity effects that have been advanced in the literature. The theoretical issues associated with liquidity effects are important because different models imply different welfare effects of monetary policies and different effects on interest rates and other variables. Also, different models of liquidity effects have different implications for optimal monetary policies. They also provide different interpretations of the data. Finally, differing implications of various models suggest potential tests of those models.

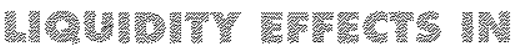

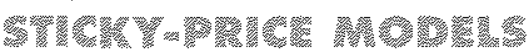

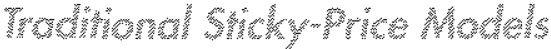

The liquidity effect is a characteristic of traditional sticky-price (Keynesian) models. Consider a model with a conventional money-demand function, and a price level that is perfectly sticky,

$$
\begin{aligned}
\log \left(\frac{m_{d}}{\ddot{p}}\right) & =\alpha_{0}+\alpha_{1} \log (y) \\
& -\alpha_{2} \log (1+i)+\varepsilon_{\mathrm{m}}
\end{aligned}
$$

where $m_{d}$ is nominal money demand, $\bar{p}$ is the pre-determined price level, $y$ is real income, $i$ is the nominal interest rate, and $\varepsilon_{i n}$ is a meanzero disturbance to money demand so that $E\left(\varepsilon_{m}\right)=0$. Given the double-log specification, the parameters $\alpha_{1}$ and $\alpha_{2}$ are income and interest elasticities, respectively.

Suppose that the money supply, $m$,

"Of cousse, these con be notr superneutralities of noney in flexi ble-price equilibrium motels, surh as in costhinnodularince models, in which the inflation tox reduces inputs of labor or capital curve), which is consistent with empirical estimates of income elasticities, and assume that real income rises by less than 10 percent in response to the exogenous 10 percent increase in nominal money. In this case, the nominal interest rate would fall to equilibrate money supply and money demand, thus generating the liquidity effect. In most neoclassical flexible-price models, however, the price level would rise sufficiently in response to a permanent increase in the money supply so that the real money supply, real income and nominal interest rates would be unchanged. ${ }^{2}$

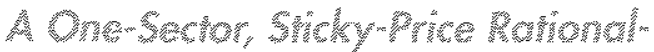 Expectotions Modd}

Though it is not difficult to generate a liquidity effect in an IS-LM model with sticky prices, further research has shown that this is not a generic feature of sticky-price models. To see why, we consider a simple neoclassical-growth model with money and exogenous price stickiness, as in recent work by Cho and Cooley (1990) and King (1991). A representative household maximizes discounted expected utility, with preferences defined over consumption of a single physical good, $c_{t}$, and leisure, $t_{i}$ :

$$
\operatorname{Max} E_{0} \sum_{t=0}^{\infty} \beta^{\prime} u\left(c_{1}, l_{t}\right) \text {. }
$$

The household faces a period budget constraint:

$$
\begin{gathered}
w_{t} n_{t}+\left(r_{t}+(1-\delta)\right) k_{t}+\frac{m_{i}+\tau_{t}}{p_{t}} \\
\geq c_{t}+k_{t+1}+\frac{m_{t+1}}{p_{t}} .
\end{gathered}
$$

The household's wealth (measured in units of the consumption good) consists of wage income, $w_{i} n_{t}$, capital income and undepreciated capital stock, $\left(r_{i}+(1-\delta)\right) k_{i}$, and the real value of money, including lumpsum monetary transfers from the government, $\left(m_{t}+\tau_{i}\right) / p_{i}$. (In this economy, the price level is simply the dollar price of the single good). The household uses its wealth to purchase consumption, and acquire new capital and new money. We assume that consumption purchases are subject to a cash- 
in-advance constraint; consumption can only be acquired with existing cash:

$$
m_{t}+\tau_{t} \geq p_{t} c_{t}
$$

A competitive firm produces the single good using a stochastic constant-returns-toscale production technology, $z_{t} f\left(K_{t}, N_{t}\right)$, that takes labor $(N)$ and capital $(K)$ as inputs. The term $z$ is an exogenous productivity disturbance with the following autoregressive law of motion:

$$
z_{t}=(1-\phi)+\phi z_{t-1}+\varepsilon_{z t}
$$

The firm maximizes profits, treating factor prices parametrically:

$$
\operatorname{Max} z_{t} f\left(K_{t}, N_{t}\right)-w_{t} N_{t}-r_{1} K_{t}
$$

Because the technology is constant returns to scale, maximum profits are zero. Profit maximizing input choices by the firms yield the following functions for factor prices (where subscripts indicate partial derivatives):

$$
\begin{gathered}
w_{t}=z_{t} f_{N}\left(K_{t}, N_{t}\right) \\
r_{t}=z_{t} f_{K}\left(K_{t}, N_{t}\right) .
\end{gathered}
$$

The resource constraint in this economy is:

$$
z_{t} f\left(K_{t}, N_{t}\right)+(1-\delta) K_{t} \geq C_{t}+K_{t+1}
$$

Remaining equilibrium conditions are given by household first-order conditions and market-clearing conditions. Efficient household choices for consumption, labor input, capital accumulation and money, with subscripts indicating partial derivatives, and $\lambda_{i}$ denoting the date-t marginal value of wealth, are:

$$
\begin{gathered}
\lambda_{t}=\beta E_{t}\left[\lambda_{t+1}\left(r_{t+1}+(1-\delta)\right)\right] \\
u_{t y}=\lambda_{t} w_{t} \\
\frac{\lambda_{t}}{p_{t}}=\beta E_{t}\left(\frac{u_{t+1}}{p_{t+1}}\right) .
\end{gathered}
$$

We assume that money growth is exogenous, and is given by the autoregressive process:
(13) $\ln M_{t}=\ln M_{t-1}$

$$
+\mu\left(\ln \left(M_{t-1}\right)-\ln \left(M_{t-2}\right)\right)+\varepsilon_{m t}
$$

Now, consider the one-period interest rate on a (nominally) risk-free bond between today and tomorrow. Although this asset will not be traded in this representative-agent economy, it is straightforward to compute the equilibrium asset price. The equilibrium interest rate implies that the representative household has, at the margin, no incentive to trade this security. The interest rate on this one-period bond is given by the relation:

$$
\left(1+i_{t+1}\right)=\frac{1}{\beta E_{t}\left[\frac{u_{c t+1}}{p_{t+1}}\right]} \frac{u_{\mathrm{ct}}}{p_{t}}
$$

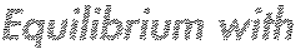

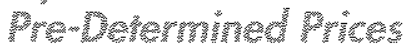

Suppose prices are set one period in advance at the expected market-clearing price. (The commodity for which the pre-determined price is an equilibrium is expected consumption conditional on information at date $t-1$.) Given that the price is pre-determined, it is necessary to specify a rule for allocations: We first assume that output in this economy is purely demand-determined. That is, the representative firm sells as much output to households as demanded at the pre-determined price. This assumption is consistent with recent sticky-price literature, as in Blanchard and Kiyotaki (1987), in which monopolistically competitive firms willingly supply extra demand, as long as price exceeds marginal cost.

Unlike the IS-LM type model discussed at the beginning of this section, it is ambiguous whether the nominal interest rate falls in response to an unexpected increase in the money stock in this sticky price economy. Assuming that the cash-in-advance constraint binds, consumption is relatively high today, which implies that the marginal rate of substitution between consumption today and tomorrow (the expected real interest rate) is low, which tends to reduce the nominal interest rate. If money growth is positively serially correlated, then expected inflation is high, which tends to increase the nominal interest rate. It is easy to see this result if we 
assume that households have perfect foresight, and that momentary utility is additively separable:

$$
u=\frac{c^{1-\rho}}{1-\rho}+v(l)
$$

Taking natural logs of the asset-pricing relation under perfect foresight, we obtain the Fisher decomposition of the nominal interest rate into a real component and a nominal component reflecting future inllation:

$$
\begin{aligned}
\dot{i}_{t+1} & \approx-\ln (\beta)+\rho\left(\ln \left(c_{i+1}\right)-\ln \left(c_{\mathrm{r}}\right)\right) \\
& +\ln \left(p_{i+1}\right)-\ln \left(p_{\mathrm{i}}\right) .
\end{aligned}
$$

Thus, the nominal interest rate falls only if the utility curvature parameter, $\rho$, is sufficiently large that the decline in the real interest rate reflecting negative-consumption growth more than offsets the increase in inflation. This typically implies that the curvature parameter $\rho$ must exceed 1 . (That is, risk aversion of the representative household exceeds that of $\log$ utility).

Note that the effect of an unexpected increase in the money stock on the nominal interest rate in this cash-in-advance economy depends on the allocation (rationing) rule. Suppose instead that output is determined by the minimum of quantity demanded and quanitity supplied, as in Barro and Grossman (1971), rather than being determined by the quantitydemanded allocation rule. That is, households will be rationed in response to a positive money shock, and firms will be rationed in response to a negative money shock. In this "short-side" case, the cash-in-advance constraint no longer binds if there is a positive money shock, and the nominal interest rate must fall to zero. (This extreme response of the nominal interest rate is an artifact of the cash-in-advance framework of this model. It would likely disappear in a similar model in which the interest elasticity of the demand for money were non-zero.)

\section{Solving and Simulduing the One-Sector Stricky-Brice Model}

To gain some insight into this issue with a more general form of preferences, we have conducted a simulation of the demanddetermined version of this model. Because the model does not possess a closed form, we computed an approximate equilibrium using a version of Marcet's (1990) procedure. We choose functional forms and parameters that have been commonly used in the business cycle literature. We assume that the momentary utility function is isoelastic, which is consistent with steady-state growth:

$$
u(c, l)=\frac{\left(c^{\psi} l^{1-\psi}\right)^{1-\rho}}{1-\rho}-1 .
$$

Production possibilities are assumed to be Cobb-Douglas:

$$
z f(K, N)=z K^{\theta} N^{1-\theta} .
$$

The discount factor, $\beta$, equals 0.99 , which implies a steady-state real interest rate of about 4 percent. The preference parameter, $\psi$, determines the share of discretionary time spent in producing market goods. We set $\psi=0.37$, which implies that households work about one-third of their discretionary time. The curvature parameter $\rho$ is set to 2 . The production parameter, $\theta$, is equal to capital's share of income and has averaged about 0.36 in the United States. The depreciation rate, $\delta$, is set to 0.025 , which implies an annual depreciation rate of 10 percent. The persistence parameter for the technology shock, $\phi$, is 0.95 , which is comparable to numbers used by Hansen (1985) and Prescott (1986). The innovation variance is set to 0.007 , which is the estimate used by Prescott (1986) and others. The serial correlation parameter for money growth, $\mu$, is 0.5 , and the innovation variance is set to 0.009 .

The experiment consists of holding the technology shock fixed at the unconditional mean, and letting the money supply increase by 1 percent at date $t$. The increase in the money stock is completely unanticipated. Unexpectedly high money growth raises real output in this model. Assuming that the cash-in-advance constraint binds, the percentage increase in consumption equals the percentage increase in the money stock. Figures 1-3 present the impulse response 
functions of capital, consumption and labor input to a 1 percent, unanticipated, permanent increase in the money stock. The capital stock increases only slightly; its increase is not sufficient to generate persistent changes in consumption or labor input. The response of the nominal interest rate to the money shock appears in Figure 4. The immediate effect of the money shock is to increase the nominal interest rate slightly: A Fisher decomposition shows that the real interest rate declines, but that the increase in expected inflation more than offsets this fall.

While we do not pursue a comprehensive analysis of this one-sector model, this example indicates that it is not necessarily easy to generate nominal liquidity effects in sticky-price models with explicit intertemporal optimization. Robert King reaches the same conclusion in a related monetary model which does not have unitary income elasticity of money demand, and which includes multi-period price setting.

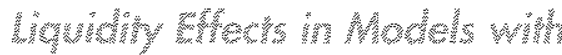 Some shidky prices}

The model discussed in the preceding section had the property that the price level was sticky in response to a monetary shock. This section analyzes the liquidity effect in an economy in which some, but not all, prices are sticky. The analysis in this section is drawn from Ohanian and Stockman (1994). The motivation behind this model is that while there is considerable evidence suggesting that some nominal prices change infrequently (see Carlton, 1989), there is also abundant evidence that many goods have prices that change frequently, such as food, automobiles, computers and gasoline. We consider a model with two physical consumption goods, $X$ and $Y$, money introduced through a cash-in-advance constraint, and complete asset markets, with the exception of the friction induced by the cash-in-advance constraint. We first analyze a very simple economy without capital. The equilibrium in this simple economy can be calculated very quickly, and as a result it is possible to evaluate the properties of this economy for a wide variety of parameter values.

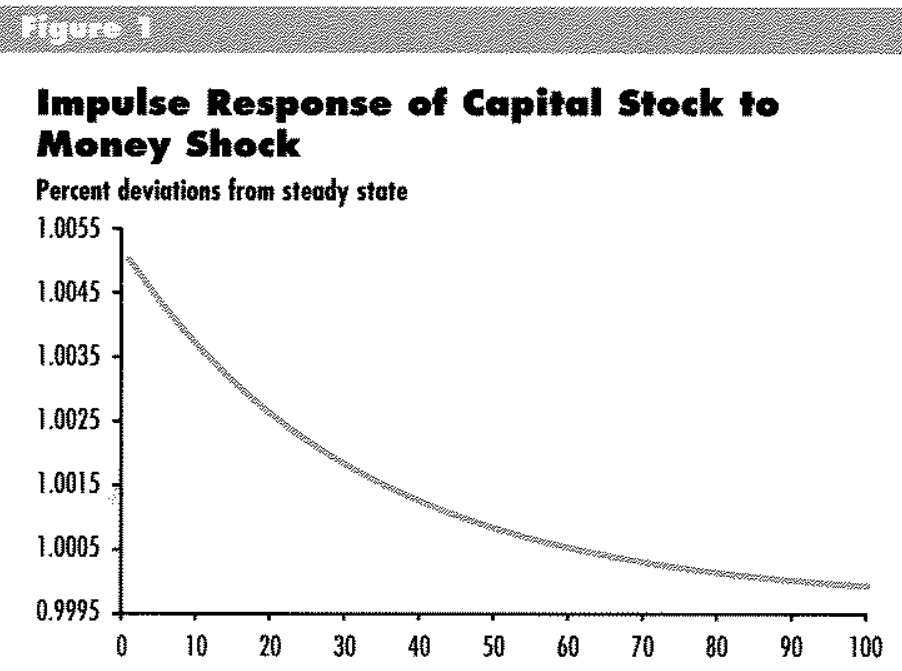

\section{(a)}

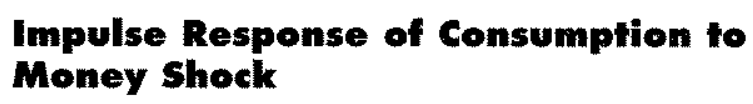

Percent deviations from steody state

1.0115

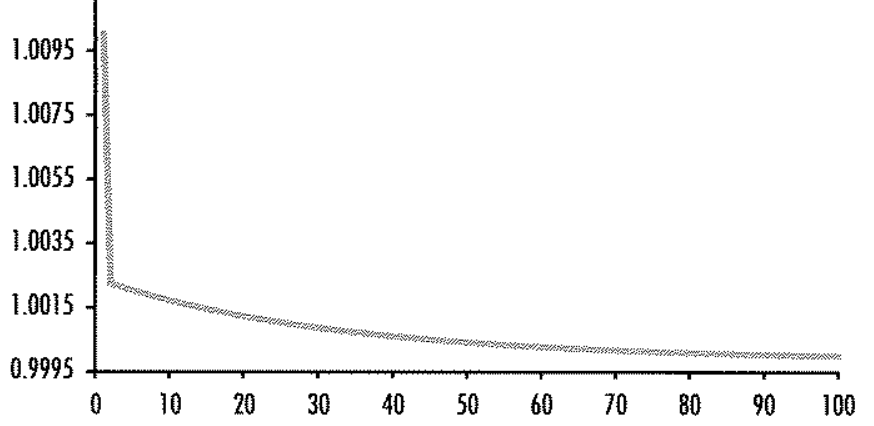

\section{3.}

\section{Impulse Response of Labor Input to Money Shock}

Percent deviations from stedy stote

1.0235

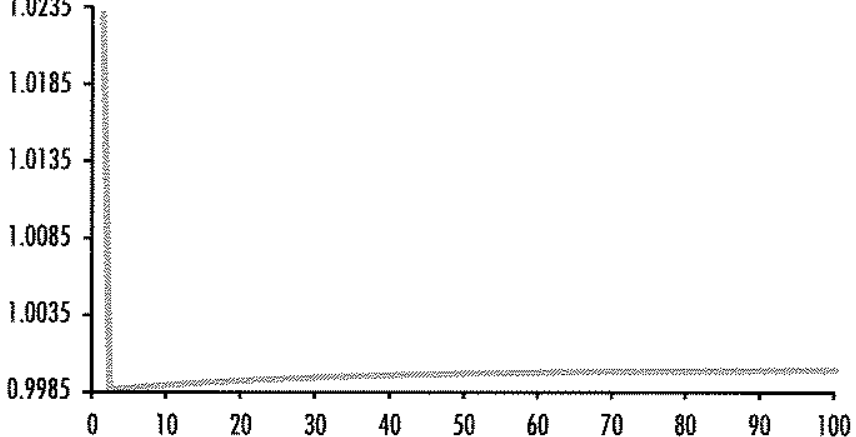



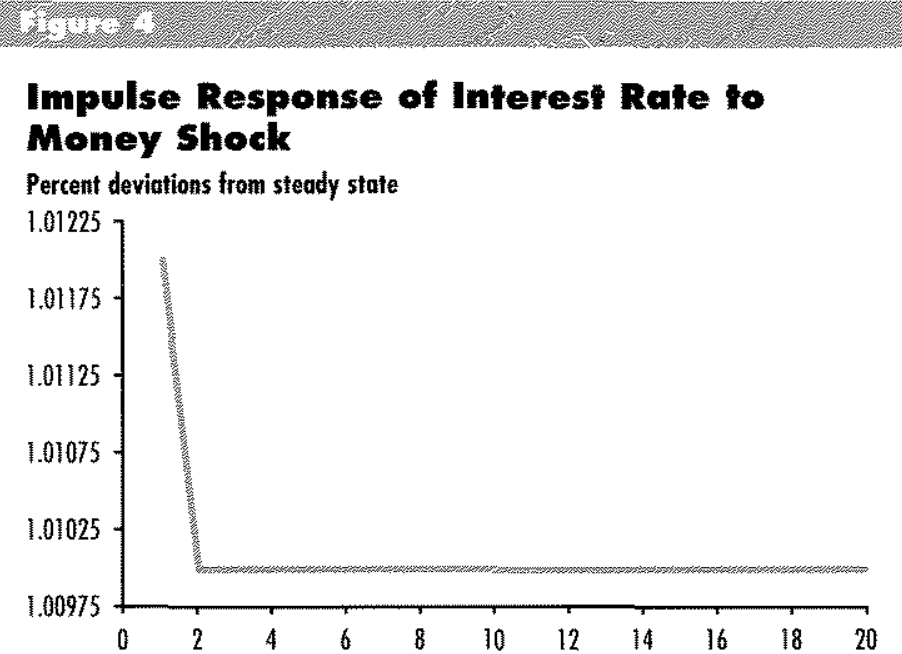

A representative household maximizes discounted expected utility:

$$
\begin{aligned}
\max & E_{0} \sum_{t=0}^{\infty} \beta^{t}\left[\frac { 1 } { ( 1 - \rho ) } \left(\alpha x_{t}^{(\sigma-1) / \sigma}\right.\right. \\
& \left.+(1-\alpha) y_{t}^{(\sigma-1) / \sigma}\right)^{(\sigma /(\alpha-1))(1-\rho)} \\
& \left.-v \cdot\left(L_{x t}+L_{\gamma t}\right)\right]
\end{aligned}
$$

subject to the sequence of constraints

$$
\begin{array}{r}
n_{t-1,}+\tau_{t}+P_{X, i-1,1} L_{X, t-1-1}^{\theta}+P_{Y, i-1} L_{Y, i-1}^{\theta} \\
-M_{t}+v_{t}\left(q_{t}+d_{i}\right)-v_{i+1, q_{i}}=0
\end{array}
$$

and

$$
M_{t}-P_{X} X_{t}-P_{y} Y_{t} \geq 0
$$

where equation 20 is a budget constraint for period-t asset markets and inequality (equation 21) is the cash-in-advance constraint which applies to period-t product markets (which immediately follow period-t asset markets, as in Lucas, 1982). The terms $x$ and $y$ refer to consumption of goods $X$ and $Y, L_{X}$ and $L_{Y}$ refer to the labor hours to produce goods $X$ and $Y, 0 \leq \theta<1$ is a parameter of the production function, $n_{t-1}$ refers to the household's money holdings at the end of period $(t-1)$ product markets, $\tau$ refers to a lump-sum transfer of money to the household from the government, $P_{X}$ and $P_{Y}$ are nominal prices, $M_{f}$ is the nominal money the household chooses as it leaves period- $t$ asset markets and enters period- $t$ product markets, $v_{i}$ is a vectot of other assets the household owns at the begimning of period $t$, with dividend vector $d$ and ex-dividend price-vector $q$. We assume that households have constant elasticity of substitution preferences across the two physical goods, where $\sigma$ is the elasticity of substitution between $x$ and $y$ and $\rho$ is a measure of overall curvature of the utility function. And $v$ is a leisure-preference parameter. $(1 / \rho$ is the elasticity of intertemporal substitution.)

Assume that the cash-in-advance constraint (equation 21) binds as an equality every period and that $\tau \equiv 0$. It is easy to see that the flexible-price perfect foresight equilibrium for this simple production economy satisfies

$$
\begin{aligned}
& M_{l}^{s}=P_{X t} L_{X l}^{\theta}+P_{Y l} L_{Y i}^{\theta}, \\
& P_{X i} \lambda_{t}=\left(\alpha \alpha x_{1}^{(\sigma-1) / \sigma}\right. \\
& \left.+(1-\alpha) y_{i}^{(\sigma-1) / \sigma}\right)^{(1-\rho \sigma) /(\alpha-1)} \alpha \mathrm{L}_{X, t}^{-\theta / \sigma} \\
& P_{\mathrm{Yis}^{\prime}} \lambda_{1}=\left(\alpha x_{t}^{(\sigma-1) / \sigma}\right. \\
& \left.+(1-\alpha) y_{1}^{(\sigma-1) / \sigma}\right)^{(1-\rho \sigma) /(\sigma-1)} \\
& (1-\alpha) L_{\gamma_{t}}^{-\theta / \sigma} \\
& v=\beta \cdot P_{X_{1}} \cdot \theta \cdot L_{X t}^{\theta-1} \cdot \lambda_{i+1}, \\
& v=\beta \cdot P_{Y \mathrm{r}} \cdot \theta \cdot L_{-\mathrm{Y}}^{\theta-1} \cdot \lambda_{t+1},
\end{aligned}
$$

where $M_{i}^{s}$ is the (exogenous and constant, because $\tau=0$ ) money supply at the end of period- $t$ asset markets and $\lambda$ is the currentvalue Lagrange multiplier on the constraint of equation 20. (Note that $\lambda=\gamma$, where $\gamma$ is the current-value tnultiplier on the cash-inadvance constraint, because of the first-order condition for the choice of $M_{t}$.) Moreover, we can solve for the nominal interest rate on a one-period nominal asset using the pricing condition:

$$
1+i=\frac{\lambda_{t}}{\beta \lambda_{t+1}} .
$$


Equthoritum When Sone Friess Are Shidcy

We now suppose that nominal prices in the $X$ industry are pre-determined: Sellers choose the nominal price $P_{X, t}$ at the end of period $t-1$. The nominal price of $Y$, on the other hand, adjusts to clear markets each period. We can vary the amount of price stickiness in the economy by varying the relative sizes of the $X$ and $Y$ industries. The nominal price of $X$ is set to equate expected quantities supplied and demanded. As in the case of the one-sector model, we assume that output in the $X$ industry is determined by the quantity demanded. An interesting feature of this setup is that it encompasses the standard Keynesian model and the flexible-price neoclassical model as special cases.

We begin with the economy in a nonstochastic, steady-state equilibrium with a constant money supply, and consider an unanticipated, permanent change in the nominal money supply at the beginning of period $t$. Real variables dated at $t+1$ and later are unaffected by this change in the money supply, but real variables at date t change because $P_{X, z}$ is pre-determined. Suppose the money supply falls permanently by 1 percent at date $t$, with $P_{x, t}$ fixed for one period. Because the quantity of $X$ produced is determined by the quantity demanded, equation 25 (describing the supply of $X$ ) does not hold in the short run. Instead, we have equations 22-24 and 26 in the four variables $L_{x, \tau}, L_{Y, t}$, $P_{\gamma, z}$ and $\lambda_{t}$, (with $\lambda_{t+1}$ taking its new steadystate value). Because a change in the money supply has no steady-state effect on $x, y$ or $L_{\chi}$, equation 23 implies that it has no steady-state effect on $P_{x t+1} \lambda_{t+1}$. Therefore, since the fall in the money supply lowers $P_{X, t+1}$ by 1 percent, it necessarily raises $\lambda_{t+1}$ by 1 percent.

Tables 1-4 present the quantitative effects of a permanent 1 percent rise in the money supply (from 10.0 to 10.1) when $\sigma=0.5$, $\theta=0.64, v=1, \beta=0.99$ and $\rho=2$. We choose the elasticity of substitution between $x$ and $y$ $(\sigma=0.5)$ to be less than the Cobb-Douglas case $(\sigma=1)$ since it seems reasonable to assume that the short-run substitutability between the two categories of goods may be relatively low. The value chosen for the production parameter,

\section{.}

Benchmark Case

\begin{tabular}{|c|c|c|c|c|}
\hline & old SS & SR & New SS & Ratio \\
\hline 1 & 4.167 & 3701 & 4.167 & -0.47 \\
\hline$p x$ & 7.925 & 7925 & 8004 & -0.99 \\
\hline py & 7925 & 8.012 & 8.004 & 0.10 \\
\hline bobot in X & 0.4869 & 0.4924 & 0.4869 & $0: 13$ \\
\hline Labor inl & 0.4869 & 0.4882 & 0.4869 & 0.27 \\
\hline $001 p 01$ of $\mathrm{C}$ & 0.6309 & 0.6355 & 0.6309 & 0.72 \\
\hline 040011 of & 0.6309 & 0.6320 & 0.6309 & 0.17 \\
\hline GIP & 1262 & 1267 & 1262 & 0.45 \\
\hline Totollobor & 0.9738 & 099807 & 09738 & 0.70 \\
\hline
\end{tabular}

\section{Y.}

Very Small Sticky-Price Sector

\begin{tabular}{|c|c|c|c|c|}
\hline & old SS & $S R$ & New SS & Ratio \\
\hline$i$ & 4.167 & 4.057 & 4.167 & -0.11 \\
\hline$p x$. & 5.346 & 5346 & 54 & -0.99 \\
\hline py & 1074 & 1085 & 10.85 & 0.02 \\
\hline tabor in $X$ & 0.1044 & 0.1053 & 0.1044 & 0.86 \\
\hline Labor in Y & 0.7248 & 0.7252 & 0.7248 & 0.06 \\
\hline Output of $X$ & 0.2355 & 0.2368 & 0.2355 & 0.55 \\
\hline Output of $Y$ & 0.8138 & 0.8141 & 0.8138 & 0.04 \\
\hline GNP & 0.9939 & 0.9943 & 0.9939 & 0.04 \\
\hline Totallabor & 0.8291 & 0.8305 & 0.8291 & 0.16 \\
\hline
\end{tabular}

$(\theta=0.64)$, is often used in the equilibrium business cycle literature, and is identical to the value used in the one-sector model. We select overall curvature of the utility function $(\rho=2)$ that is consistent with empirical estimates, and is also identical to the value used in the onesector model. Also, $v$ is a leisure preference parameter and does not play an important role for the experiments we conduct. ${ }^{3}$

The first column shows the variables of interest: the nominal one-period interest rate (in percent); the nominal prices of $X$ and $Y$; labor input in each industry; output in each industry; real GNP evaluated at the equilibrium prices and production shares; and the total labor input. The second column displays the old steady-state (Old SS) levels of these variables, before the change in money. The SR

\footnotetext{
${ }^{3}$ We have onthyzed specifications with dilferent preferences over lessure, ond the resilts ore qualitatively similes to those reported below. For example, if ateferences are lagarithmic in leisure, the effect of a money shock on interest rates is about 70 peccent as large os it the cose of hineal preferences over leisure.
} 


\section{Cas}

\section{Intermediate Case}

\begin{tabular}{|c|c|c|c|c|}
\hline & old SS & SR & New SS & Ratio \\
\hline 1 & 4.167 & 3861 & 4.167 & -0.31 \\
\hline$p x$ & 7.032 & 7.032 & 7.103 & -0.99 \\
\hline py & 8.95 & 9045 & 904 & 0.06 \\
\hline tabor in $)$ & 0.3991 & 0.3223 & 0,3191 & 1.01 \\
\hline Lfobsi 14 Y & 0.6235 & 0.6246 & 0.6235 & 0.18 \\
\hline 0 usput of $x$ & 0.4814 & 0.4845 & 0.4814 & 0.65 \\
\hline oupur ofl & 07391 & 07399 & 0.7391 & 011 \\
\hline GNP & 1205 & 1208 & 1205 & 0.24 \\
\hline Totol folor & 0.9426 & 09469 & 0.9426 & 0.46 \\
\hline
\end{tabular}

\section{(2)}

\section{Smaller Elasticity of} Intertemporal Substitution

\begin{tabular}{|c|c|c|c|c|}
\hline & Old SS & SR & New SS & Ratio \\
\hline & 4.167 & 3.6 & 4.167 & -0.57 \\
\hline pr & 6.137 & 6.137 & 6.199 & -1.00 \\
\hline py & 8103 & 8.139 & 8.184 & 0.06 \\
\hline Labor in X & 0.3546 & 0.3582 & 0.3546 & 1.00 \\
\hline Eabor in $Y$ & 0.7672 & 0.7685 & 0.7672 & 0.17 \\
\hline Output of $X$ & 0.5151 & 0.6183 & 0.5151 & 0.64 \\
\hline Outpot of $Y$ & 0.844 & 0.8449 & 0.844 & 0.11 \\
\hline GNP & 1.337 & 1.339 & 1.337 & 0.21 \\
\hline Iotal labor & 1.122 & 1.127 & 1.122 & 0.43 \\
\hline
\end{tabular}

column shows the short-run effects of the 1 percent rise in money (while the nominal price of $X$ is fixed at its previous level). The fourth column (New SS) shows the new steady state, and the column labeled ratio displays the percentage by which a variable falls short of, or exceeds, its new steady state level. For the interest rate, this column shows the difference between the short-run and steady-state interest rates.

Table 1 shows the results when $\alpha=0.5$, so that the sticky-price sector represents half of the economy's output and half of all labor is employed in the sticky-price sector. A permanent 1 percent rise in the money supply is neutral in the long run, with a 1 percent rise in nominal prices and no effects on real variables.
But in the short run, with $p_{x}$ pre determined, real GNP rises about 0.45 percent. There are significant differences across sectors: Output in the sticky price sector rises 0.72 percent, while output in the flexible-price sector rises 0.17 percent. The rise in money raises the nominal price of $Y$, which reduces the rela tive price of $X$. This taises the quantity of $X$ demanded and creates excess demand in the $X$ industry. Since output of $X$ is determined by the quantity demanded, output of $X$ rises. Output of $Y$ rises less because consumers substitute into purchases of $X$. (If the elasticity of substitution were greater than 1 , this substitution would be larger and the output of $Y$ would fall.) Notice that the nominal price of $Y$ rises by about as much as if the price of $X$ were flexible. It overshoots its long-run equilibrium by one-tenth of 1 percent (it would undershoot if the elasticity of substitution between $X$ and $Y$ were greater than 1 ).

The rise in the money supply has a short-run "liquidity effect" on the nominal interest rate. In Table 1 , the nominal interest rate falls 47 basis points, from 4.17 percent to 3.70 percent, in the short run. Because expected inflation is positive (the CPI is expected to rise another 0.50 percent), this represents a fall in the real interest rate (measured in terms of the output bundle) of about 1 percentage point. Notice that the liquidity effect occurs despite the introduction of money through a cash-in-advance constraint, which (when binding, as in these examples) builds in a zero interest-elasticity of the demand for money.

Table 2 shows that a change in the money supply can have a substantial liquidity effect on nominal and real interest rates in the short run even if only a small fraction of the economy has sluggish prices. This table presents results with the same parameter values as in Table 1, but with $\alpha=0.04$, so that the sticky-price sector accounts for only about 12 percent of employment. A permanent 1 percent rise in money reduces the nominal interest rate by about 12 basis points. Table 3 shows that with $\rho=2$, the liquidity effect is somewhat smaller if one-third of labor is employed in the sticky-price sector. If, however, the elasticity of intertemporal substitution is one-third $(\rho=3)$ rather than 
one-half, the interest rate falls 57 basis points when one-third of labor is employed in the sticky-price sector (see Table 4). With $\rho=3$, the nominal interest rate falls 27 basis points even if the sticky-price sector accounts for only 15 percent of employment, and raising $\rho$ from 3 to 4 further doubles the size of the interest rate response, holding fixed the share of the economy with sluggish prices.

These examples demonstrate that a significant liquidity effect is consistent with a relatively small sticky price sector. A further analysis of the relationship between the size of the sticky-price sector and the response of interest rates to a money shock is presented in Figure 5. This plot displays the $(\rho, \alpha)$ combinations that generate the midpoint estimate of the liquidity effect reported by Christiano and Eichenbaum (1992b), and shows that reasonabie values of $\rho$ combined with a small sticky-price sector are consistent with their estimates for U.S. data. While the size of the liquidity effect depends on the parameter $\rho$, in all other respects the responses of the economy to an increase in the money supply are virtually unaffected by changes in the elasticity of intertemporal substitution. ${ }^{*}$

\section{A wa Conntry Model}

In previous work, such as Stockman and Ohanian (1994), we examined the effects of money supply changes in a two-country world in which some sectors of the economy have nominal prices that are sticky in the short run and other sectors have flexible prices. We showed that money supply changes have liquidity effects (a fall in the money supply raises the real and nominal interest rate) both within and across countries, and creates a crosscountry, real interest rate differential.

We discussed a two-country model in which each country produces and consumes two internationally tradable goods, $X$ and $Y$, using only labor as an input. There are two monies introduced through cash-in-advance constraints with the usual convention in which sellers' currencies are the medium of exchange for all transactions. Because the two countries are identical ex ante, we describe only the domestic country. A representative household in the home country maximizes

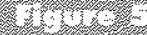

\section{Rho/Alpha Pairs Yielding Estimated (Midpoint) Liquidity Effects} Corvature of utility function (rho)

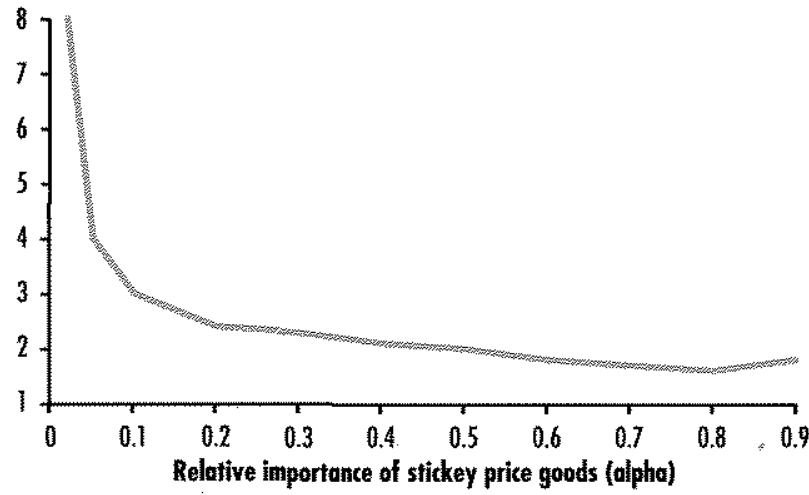

$$
\begin{aligned}
E_{\theta} & \sum_{t=0}^{\infty} \beta^{\prime}\left[\frac { 1 } { ( 1 - \rho ) } \left(\alpha x_{t}^{(\sigma-1) / \sigma}\right.\right. \\
& \left.+(1-\alpha) y_{t}^{(\sigma-1) / \sigma}\right)^{(\sigma /(\sigma-1))(1-\rho)} \\
& \left.-v\left(L_{\chi_{t}}+L_{\gamma_{t}}\right)\right]
\end{aligned}
$$

subject to the sequence of budget constraints

$$
\begin{aligned}
& P_{X, t-1} k_{X, t-1} L_{X, t-1}^{\delta}+P_{Y, t-1} k_{Y_{t}-1} L_{Y, t-1}^{\delta} \\
& +v_{t}\left(q_{\mathrm{t}}+d_{\mathrm{t}}\right)+\tau_{\mathrm{t}}-v_{t+1} q_{\mathrm{t}}-M_{t}-e_{\mathrm{i}} N_{t}=0
\end{aligned}
$$

and sequences of the two cash-in-advance constraints,

$$
\begin{aligned}
& M_{t}-\min \left\{\bar{x}_{t}, x_{t}\right\} P_{X_{t}} \\
& -\min \left\{\bar{y}_{t}, y_{t}\right\} P_{Y_{t}}=0
\end{aligned}
$$

and

$$
\begin{aligned}
& N_{t}-\max \left\{x_{t}-\bar{x}_{t}, 0\right\} P_{X t}^{*} \\
& -\max \left\{y_{t}-\bar{y}_{t}, 0\right\} P_{y_{t}}^{+}=0
\end{aligned}
$$

where equation 29 is a budget constraint for period-t asset markets and equations 30 and 31 are the cash-in-advance constraints that apply to period-t product markets. The terms $x_{t}$ and $y_{t}$ refer to total home consump-

\footnotetext{
in fuiure wolk, we plan to onalyze ligitidity affects in o version of this hylind model with copitg accutatufion and o mixture of moletenty and technology shoks.
} 


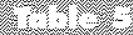

\section{Home Money Falls from 10 to 9.8}

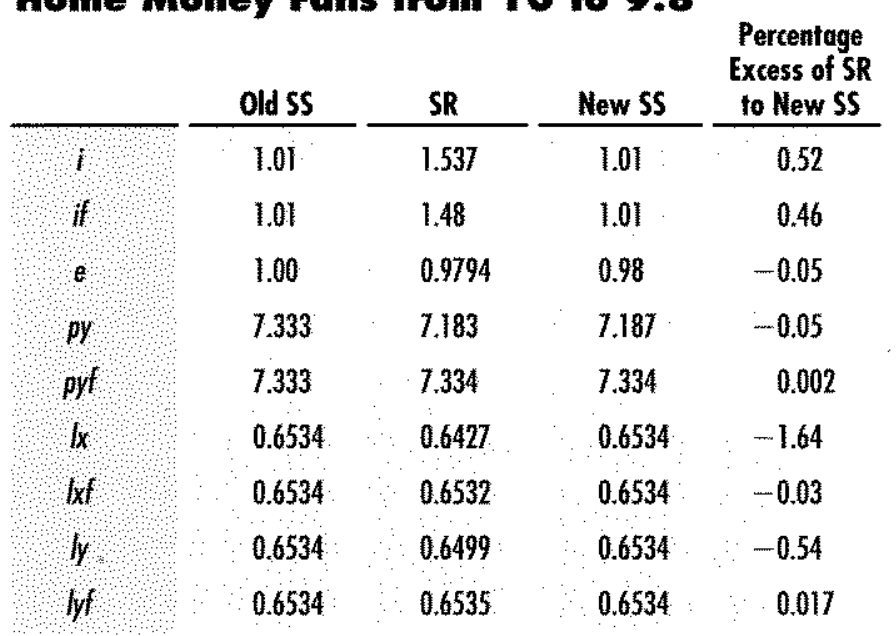

tion of goods $X$ and $Y$, regardless of where the goods were purchased, $\bar{x}_{i}$ and $\bar{y}_{4}$ refer to home production of the two goods, $M_{i}$ is the home household's stock of home money at the beginning of the product market, $N_{t}$ is its stock of foreign money, used for purchasing imports (if imports are positive), and $e$ is the exchange rate (in units of home money per unit of foreign money).

We assume that assets cannot be traded conditional on monetary transfers or taxes (positive or negative $\tau$ ), so any decrease in the home money supply is financed by lumpsum taxes (negative $\tau$ ) on households in the home country only, and any decrease in the foreign money supply directly affects only foreign households. Assuming $\tau \equiv \tau^{*} \equiv 0$, where $\tau^{*}$ is the transfer or tax in the foreign country, and $k_{X, t}=k_{X^{*}, t}=k_{Y, t}=k_{Y^{*}, t}=1$ for all $t$. we showed that one flexible-price equilibrium is the same as in a closed economy, with no international trade or foreign money holding.

We assume that $P_{x}$ and $P_{x}^{* *}$ (the foreigncurrency nominal price of $X$ produced and sold in that country) are pre-determined, chosen one period in advance. The nominal prices $P_{Y}$ and $P_{Y}^{*}$, on the other hand, are flexible. Assuming flexible exchange tates and holding constant the foreign money supply $N^{s}$, we consider a small, unanticipated, permanent fall in $M_{1}^{S}$ (the home money supply) starting from a nonstochastic steady-state equilibrium with constant money. In situa- tions of excess supply, buyers purchase from sellers in the country with the lowest price (adjusted for the exchange rate). When prices are equal in both countries, buyers purchase first from sellers in their own country. We assume that in situations of excess demand for a good in some country, buyers residing in that country are first in line and buyers from the other country are last in line to buy that good. ${ }^{5}$

Necessary conditions for home-currency and foreign-currency bonds yield expressions for one-period nominal interest rates like 2.10 that, along with the law of one price for good $Y, P_{Y}=e P_{Y}^{*}$, and interest parity imply:

$$
e_{t}=e_{t+1} \frac{\lambda_{t}^{*}}{\lambda_{t+1}^{*}} \frac{\lambda_{t+1}}{\lambda_{t}}
$$

where $\lambda^{*}$ is the multiplier on the foreign representative household's current-period budget constraint. Equation 15 follows directly from the usual expression of interest parity $\left(e^{\prime} / e=(1+i) /\left(1+i^{*}\right)\right)$ and the standard asset-pricing equations for riskless nominal one-period bonds in each currency. In addition, we need the separate budget constraints for home and foreign households. The home household can buy (or sell) one-period nominal bonds $B$ at the price $1 /(1+i)$.

Table 5 shows the effects of a permanent, unexpected, 2 percent fall in the home country's money supply (from 10.0 to 9.8), starting from a steady-state equilibrium with a constant money supply and price level. We hold fixed the foreign money supply in this initial exercise and assume $\alpha=0.5, \sigma=0.5, \delta=0.9, v=1$, $\beta=0.99$ and $\rho=2$. This implies that half of GDP in each country consists of output of good $Y$, the relative price of $Y$ in terms of $X$ is initially unity, the exchange rate is initially $l$, and the real (and nominal) interest rate is $1 / \beta-1$. Since $\sigma<1$, the two goods are relatively poor substitutes. We also assume there is no initial international indebtedness, so initially the countries are identical and there is no international trade. (After a change in the money supply in one country - or in both- $B$ can become non-zero and can remain non-zero in the new steady state.)

The first column of Table 5 shows the endogenous variables: the nominal price of $Y$ 
in the home and foreign countries (py and pyf); the nominal interest rate (in percent) in the home and foreign countries ( $i$ and if); the exchange rate (e); labor inputs in the $x$ industry in the home and foreign countries ( $k x$ and $l x f)$; and labor inputs in the $y$ industries in the home and foreign countries (ly and $l y f)$. The second column, Old SS, shows the old steady-state levels of the variables (before the change in money) from which the analysis begins. The SR column shows the short-run effects of the fall in money (while the nominal price of $X$ is fixed at its previous level for one period). The New SS column shows the new steady state, and the column labeled percent shows the percentage by which a variable falls short of or exceeds its new steady-state level. For the interest rate, this column presents the difference between interest rates in the short run and in the new steady state.

The 2 percent fall in money leads, in the long run (New $S S$ column), to a 2 percent fall in the nominal prices of goods $X$ and $Y$, from 7.333 to 7.187 . (The new steady-state relative price of $Y$ in terms of $X$ is 1 , so the new price of $X$ is also 7.187.) The interest rate is unaffected in the long run by the onetime change in the level of money, and the exchange rate falls 2 percent, from 1.00 to 0.98 , in the long run. Long-rum levels of employment in each industry in the home country ( $l x$ and $l y$ ) are unaffected, as are foreign employment levels in each industry ( $k f$ and (yf) and long-run levels of output in each industry and in each country.

While the unexpected change in money is almost neutral in the long run ("almost" because it redistributes wealth and so has permanent effects), it is not neutral in the short run. The impact effect of the unexpected fall in home money is to raise the home-country nominal interest rate by 53 basis points. If one interprets this as a quarterly model (since the discount parameter is 0.99 per period), with one-quarter nominal price stickiness in the $X$ industry, then the steady-state interest rate is 1.01 percent per quarter, or 4.04 percent per year. Then the 2 percent fall in home money raises the annualized home nominal interest rate by 211 basis points, to 6.15 percent per year. The foreign nominal interest rate also rises, by 47 basis points, on a per-

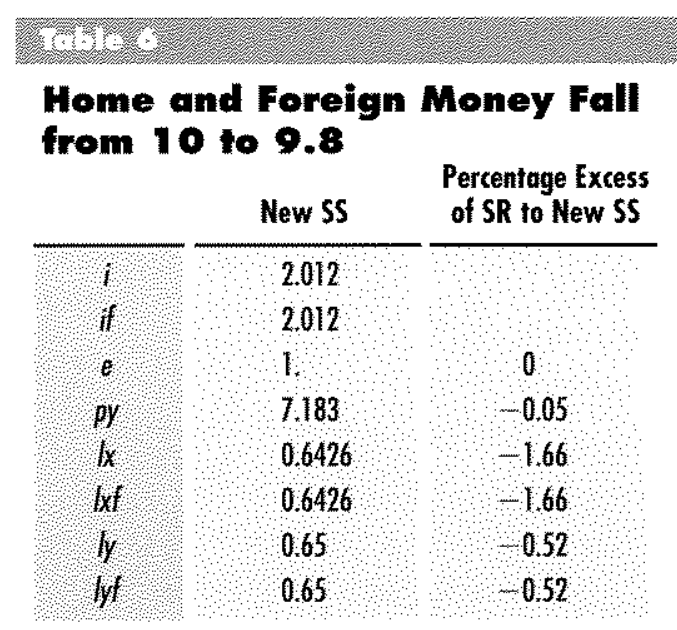

period basis, which is 188 basis points on an anntalized basis with this interpretation. The home nominal interest rate is then 20 basis points above the foreign rate on an annualized basis. This is reflected also in a slight overshooting of the exchange rate in the short run (it falls 0.05 percent below 0.98 ) followed by a small, expected (and actual) appreciation of home currency. Employment in the home country falls in both industries, particularly in the $X$ industry with sticky prices. Overall output is unchanged in the foreign country, though there is a small sectoral reallocation of production from the $X$ industry to the $Y$ industry.

The short-run appreciation of home currency, combined with the stickiness of both the home-money price of $X$ sold at home and the foreign-money price of $X$ sold abroad, implies that $X$ is cheaper in the foreign country than in the home country, creating excess demand for $X$ in the foreign country and excess supply in the home country. Foreigners are unconstrained in buying good $X$ in their own cotuntry and home residents, who are last in line there, import $X$ and buy the rest from sellers in their own country.

Table 6 shows the case in which both countries reduce their money supplies by the same percentage. The result is the same in each country as in a closed economy, and there is no international trade in either the short run or in the new steady state. The table shows the effects of an unexpected, permanent, 2 percent fall in money in both countries. This has identical effects in the two countries, 


\begin{tabular}{|c|c|c|}
\hline \multicolumn{3}{|c|}{$\begin{array}{l}\text { Foreign Money Falls to } 9.7 \text {, } \\
\text { then to } 9.80098 ; \text { Home } \\
\text { Money Falls to } 9.8\end{array}$} \\
\hline & New SS & $\begin{array}{l}\text { Percentage Excess } \\
\text { of SR to New SS }\end{array}$ \\
\hline 1 & 3.041 & \\
\hline if: & 3.041 & \\
\hline$e$ & 1. & 0 \\
\hline$p y$ & 7.18 & -0.10 \\
\hline$d x$ & 0.6463 & -1.08 \\
\hline $\mid x f$ & 0.6317 & -3.31 \\
\hline$y$ & 0.6466 & -1.04 \\
\hline lyf & 0.6466 & -1.03 \\
\hline
\end{tabular}

so we can discuss only the home country. The fall in money reduces aggregate nominal spending, which reduces the nominal price of good $Y$. Because $P_{X}$ is fixed in the short run, this increases the relative price of $X$, so consumers substitute good $Y$ for good $X$, which further reduces output of $X$ and works against the fall in spending on $Y$. If the elasticity of substitution in consumption, $\sigma$, were 1 , output in the $Y$ sector would remain unchanged and the nominal price of $Y$ would fall by 2 percent. With $\sigma<1$, output of $Y$ falls along with output of $X$ and $P_{Y}$ overshoots its longrun fall. (If $\sigma>1$, output of $Y$ rises and its nominal price undershoots its long-run fall.)

One way for the foreign country to peg its exchange rate (in the absence of any other shocks) is to change its money supply in proportion to the change in the home money supply; in this model, there are other paths of monetary policy that also result in a pegged exchange rate. But these policies have vastly different effects on real and nominal interest rates.

Suppose the home country's money supply falls by 2 percent as before, and suppose the foreign country pegs its exchange rate at unity. Suppose also that the foreign government can credibly commit to a furure path for the money supply. Because nominal prices are set one period in advance, for only one period, anticipated future changes in money can be fully incorporated into price-setting behavior. Table 7 shows the results of a foreign mone-

\begin{tabular}{|c|c|c|}
\hline \multicolumn{3}{|c|}{$\begin{array}{l}\text { Foreign Money Falls to } 9.85 \text {, } \\
\text { then to } 9.79952 ; \text { Home } \\
\text { Money Falls to } 9.8\end{array}$} \\
\hline & New SS & $\begin{array}{l}\text { Percentage Excess } \\
\text { of SR to New SS }\end{array}$ \\
\hline 1 & 1.503 & \\
\hline$f$ & 1.503 & \\
\hline$e$ & 1. & 0 \\
\hline$p y$ & 7.185 & -0.03 \\
\hline$x$ & 0.6407 & -1.94 \\
\hline $\mid x f$ & 0.648 & -0.83 \\
\hline$y$ & 0.6518 & -0.26 \\
\hline yt & 0.6517 & -0.26 \\
\hline
\end{tabular}

tary policy that reduces the foreign money supply by 3 percent from $M^{5 *}=10$ to $M^{5 *}=9.7$ in the short run (while the home money supply falls from 10 to 9.8), and then changes $M^{5 *}$ to 9.80098 in the long run, assuming that $\alpha=0.5, \sigma=0.5, \delta=0.9, v=1, \beta=0.99$ and $\rho=2$, as in Table 5 . The exchange rate remains at exactly 1 , but the rise in world interest rates of 203 basis points exceeds the 100 basis point rise that occurs along the baseline path.

Table 8 shows the results when the foreign money supply falls less than the baseline case: It falls from 10 to 9.85 for one period and then permanently goes to 9.79952 (while home money falls to 9.8 ). We continue to assume $\alpha=0.5, \sigma=0.5, \delta=0.9, v=1, \beta=0.99$ and $\rho=2$. If the fall to 9.85 were permanent, foreign currency would depreciate and $X$ would be cheaper in the foreign country. This would add to excess supply for $X$ in the home country and reduce excess supply of $X$ in the foreign country. This occurs up to the point at which the relative price is unity, that is, at an unchanged exchange rate. In this case, the rise in world interest rates is smaller ( 49 basis points) than in the baseline case, and similar to the rise in Table 5, even though the size of the change in the money supply is different. Finally, Table 9 shows the results when the foreign money supply falls even less in the short run-from 10 to 9.9 before permanently going to 9.79904 . In this case, there is no nominal liquidity effect (though the real interest rate falls). If the home money 


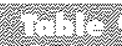

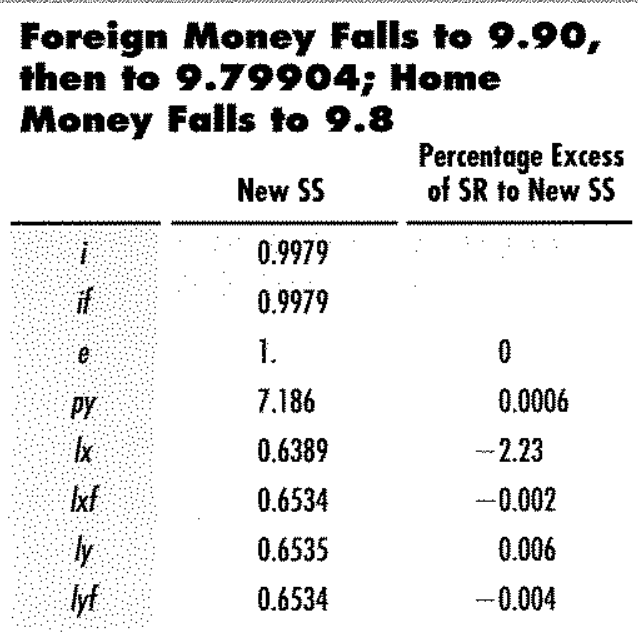

supply falls by only 0.5 percent in the short run, but the exchange rate is pegged by a commitment to future policy, then the nominal interest rate accually falls in each country (though, again, the real rate rises).

These tables illustrate that real and nominal interest rates do not depend solely on domestic monetary policy. Foreign policy and expected future domestic and foreign policies can create significant changes in the responses of both real and nominal interest rates. In particular, even the sign of the interest rate response to domestic monetary policy depends on foreign monetary policy. In addition, the response of nominal interest rates to changes in the money supply is highly nonlinear. That nonlinearity, illustrated by these tables, suggests that linear statistical analysis may miss key features of the relations between money and interest rates.

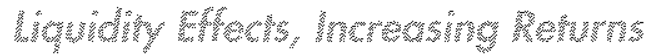

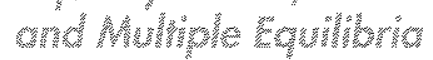

A very different model with sticky prices has been analyzed by Beaudry and Devereux (forthcoming). An infinitely lived representative household maximizes discounted expected utility:

$$
\operatorname{Max} E_{0} \sum_{t=0}^{\infty} \beta^{t}\left(\ln \left(c_{t}\right)-\eta_{n_{t}}\right) .
$$

Beaudry and Devereux make use of the Rogerson-Hansen construct, which implies that the utility function for the representative household is linear in leisure.

Final goods, $Y$, are produced from an isoelastic technology using intermediate inputs,

$$
Y=\left[\int_{0}^{\infty} m(i, t)^{\phi} d i\right]^{\frac{1}{\phi}},
$$

where $m(i)$ is the amount of intermediate input used in the production of final goods; $\omega$ represents the measure of intermediate goods-producing firms and is fixed exogenously. Intermediate-goods firms produce output from an increasing returns-to-scale technology that uses capital and labor,

$$
m(i, t)=z_{\mathrm{r}} \mathrm{F}\left(K_{\mathrm{it}}, N_{i t}\right)^{\gamma}
$$

where the degree of increasing returns is indexed by $\gamma, z_{t}$ is an exogenous technology shock and the log of $z$ is assumed to follow a random walk. Money plays a very different role in this economy relative to the other models discussed in this article. Households have no demand for money in this economy; instead, cash is held by banks because it reduces intermediation costs. Banks accept deposits from households and lend to intermediate-goods producers, who must finance capital inputs before selling their product to final-goods producers. The representative bank's intermediation cost function is assumed to be isoelastic in real balances and deposits:

$$
B\left(\frac{M}{P}\right)^{(1-t)} D^{T} .
$$

It is assumed that $\tau>1$, so that costs are reduced by acquiring real balances. Banks are owned by households and maximize the present discounted value of cash llows,

$$
\operatorname{Max} \sum_{i=0}^{\infty} \Omega_{i}\left(S_{i}\right) C F\left(S_{i}\right) d S,
$$

where $\Omega$ is a state-contingent pricing function and $C F$ is the bank's cash flow.

Final-goods producers are price takers, but intermediate-goods producers are monopolistic competitors. The increasing returns parameter $\gamma$ plays a fundamental 
role. In models with substantial increasing returns, there is a continuum of stationary equilibria. This occtrs because, with large enough increasing returns, the eigenvalues governing the policy functions are both outside the unit circle and the model no longer has the standard saddlepath property. Since there are multiple equilibria, the authors choose the equilibrium in which nominal prices do not respond to current innovations to money or technology. Sticky prices in this economy have a much different implication than in standard sticky-price setups. In conventional sticky-price models, nominal prices would change in response to monetary or technology innovations if that were possible. In the Beaudry and Devereux economy, however, there is no ex post regret in that no producer has an incentive to change his price after shocks are revealed. Monetary and technology shocks generate substantial changes in economic activity in this model. In particular, thete are large and persistent increases in output, consumption and investment in response to either type of shock. Moreover, an unanticipated increase in money leads to a significant and prolonged reduction in the nominal interest rate. With strong increasing returns, this is one of the few models that has internal propagation mechanisms capable of generating persistent liquidity effects.

However, the model generates only a nominal liquidity effect and not a real liquidity effect. In fact, monetary expansion raises the real interest rate in this model. (Because preferences are separable over consumption and leisure, marginal utility of consumption depends only on date $t$ consumption, so a rising real rate is implied by the consumptionEuler equation.) So the fall in the nominal rate is due entirely to substantial, persistent deflation induced by the monetary shock.

The channel through which money affects real quantities in this model differs significantly from the monetary transmission mechanisms in the other models discussed in this article. In fact, an increase in the money stock in this economy is isomorphic to a favorable technology shock that affects financial intermediaries. An increase in the stock of money, combined with sticky prices, results in higher real balances and raises the productivity of the banking sector. Lower intermediation costs, with strong increasing returns, lead to the substantial increase in output that occurs in this model.

The striking feature of this model is that small monetary shocks lead to significant and persistent liquidity effects, as well as large, persistent increases in real quantities. Of course, the very strong internal propagation mechanisms in the model that make these phenomena occur have not been established. Large increasing returns are required in this economy, which raises a number of questions. If actual production technologies exhibit economies of scale in this range, we would expect to see greater temporal concentration of production (periods of very high production, followed by periods of no production). The volatility of output, consumption, investment and labor input in this increasing-returns model is almost surely much greater than the corresponding volatility in the data. In addition, this model suggests large profits (or high per-period fixed costs) for business enterprises that are not obviously evident in the data. Finally, with even a small interest elasticity of money demand, the model would imply a large effect on capital accumulation. output and other variables of a change it. secular inflation, because a rise in inflation would operate like a tax on financial intermediation (analogous to a negative monetary shock in their model).

The nominal liquidity effect and inverse real liquidity effect implied by this model reflect the fact that an increase in the money stock leads immediately to a sharp deflation. Of course, the standard interpretation of lic uidity effects is that monetary increases are associated with lower nominal and real interest rates, and it is perhaps not surprising that a model in which an increase in the nominal money stock leads to a future increase in the nominal value of money reduces nominal interest rates. Though some vector autoregressions suggest that nominal prices do not immediately increase in response to a monetary shock, it is not yet an established empirical fact that higher money leads to a falling price level over horizons corresponding to business cycle frequencies, as is the case in the Beaudry and Devereux model. 


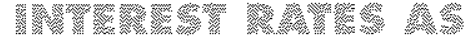

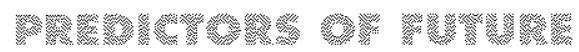

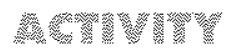

It is reasonably well established that short-term interest rates rise prior to recessions. These correlations have been interpreted as important evidence for the existence of significant liquidity effects, and for monetary business cycle models. In this section, we consider a very simple equilibrium model in which increases in nominal interest rates precede economic downturns, but the correlations between nominal interest rates and future changes in output are due to an exogenous shock. This model is used to illustrate in a simple way that there are alternative interpretations of these correlations that are consistent with neoclassical economic theory and observations.

This section is drawn from Cooley and Ohanian (1990). Consider a representative household with preferences given by:

$$
\operatorname{Max} E \sum_{i=0}^{\infty} \beta^{t} \frac{c_{i}^{i-\sigma}-1}{1-\sigma}
$$

Consumers maximize the expected present value of utility subject to the budget constraint:

$$
\begin{aligned}
& m_{t}+\tau_{t}+R_{t} b_{t}+z_{t}\left(q_{t}+p_{t} d_{t}\right) \\
& \quad \geq p_{t} c_{t}+m_{t+1}+b_{t+1}+z_{t+1} q_{t}
\end{aligned}
$$

and the cash-in-advance (asset market) constraint:

$$
R_{l} b_{l}+m_{\imath}+\tau_{t} \geq p_{\imath} c_{t}+b_{i+1} .
$$

The budget constraint states that consumer wealth, which consists of nominal money holdings $\left(m_{t}\right)$, a lump-sum monetary transfer $(\tau)$, interest and principal on oneperiod bonds $\left(R_{t} b\right)$, and the value of equity, $z_{i}\left(q_{i}+p_{i} d_{t}\right)$, must be sufficient to finance consumption $\left(c_{t}\right)$ new money $\left(m_{t+1}\right)$, new one-period debt $\left(b_{t+1}\right)$ and new equity $\left(z_{t+1} q_{t}\right)$.

The price level for the economy is given by $p_{\text {: }}$. The equilibrium for this model is straightforward: Consumption of the representative agent must be equal to the endowment $(d)$, the equilibrium prices of equity and bonds insure that the agent is willing to hold equity and there is no incentive for an agent to issue debt.

For current purposes, we assume initially that money grows deterministically:

$$
m_{t+1}=G_{t} M_{t}, \quad G_{t} \geq 1 .
$$

The endowment process is stochastic, and is the only source of uncertainty in this model. One-period debt is specified as sure nominal debt: One dollar today yields $R$ dollars tomortow, $R \geq 1$. Since this is a representative-agent economy, this security will be in zero-net supply, but the asset can be priced by using the household's marginal condition:

$$
\mathrm{I}=\beta \mathrm{E}_{i}\left[\left(\frac{c_{t}}{c_{t+1}}\right)^{\sigma} \frac{P_{i}}{P_{t+1}} R_{t+1}\right] .
$$

For analytical convenience, we assume that the endowment is generated by a $\log$ normal distribution. This implies that the one-period interest rate is given by:

$$
\begin{aligned}
\ln \left(R_{t}\right) & =-\ln (\beta)-\frac{(1-\sigma)^{2}}{2} \operatorname{var}\left(\Delta \ln \left(c_{t+1}\right)\right) \\
& +\ln \left(G_{t+1}\right)+(\sigma-1) E\left[\Delta \ln \left(c_{t+1}\right)\right],
\end{aligned}
$$

where $\operatorname{\Delta in}\left(c_{i+l}\right)$ is defined as the growth rate of consumption between today and tomorrow.

Suppose that the log of the endowment follows an integrated process:

$$
\ln \left(c_{i+1}\right)=\alpha+\ln \left(c_{t}\right)+b(L) \varepsilon_{t},
$$

where $b(L)$ is a polynomial in the lag operator $L$ and is square summable, and $\varepsilon_{\mathrm{t}}$ is an i.i.d. random variable with $E(\varepsilon)=0, E\left(\varepsilon^{2}\right)=v^{2}$.

Defining $d_{k}=\sum_{i=0}^{k} b_{1}$, it can be shown that the one-period nominal interest rate in this economy is given by:

$$
\begin{aligned}
\ln \left(R_{t}\right) & =-\ln (\beta)-\frac{(1-\sigma)^{2}}{2} v^{2}+(\sigma-1) \alpha \\
& +(\sigma-1)\left[\sum_{k=0}^{\infty}\left(d_{k+1}-d_{k}\right) \varepsilon_{t-k}\right] \\
& +\ln \left(G_{t+1}\right) .
\end{aligned}
$$


Note that in this economy, the nominal interest rate necessarily rises prior to a recession if the risk-aversion coefficient $(\sigma)$ is less than 1. This is because if the economy is at a cyclical peak, then the term

$$
\left[\sum_{k=0}^{\infty}\left(d_{k+1}-d_{k}\right) \varepsilon_{t-k}\right]<0 .
$$

Moreover, if one compares the spread between short-and long-term debt, then it is also the case that the yield curve necessarily inverts prior to a recession, and this is a strong feature of the data. The explanation for this is due to expected inflation. If households anticipate the endowment to fall next period, there are two forces at work on the interest rate. First, given the constant growth rate rule for money, higher expected inflation tends to push up the nominal rate. A falling endowment, however, implies that the real rate will fall. If risk aversion is less than unity, then inflation risk is more important than endowment risk, and the interest rate rises prior to a downturn.

Of course, the price level in this model is countercyclical; high price levels (and inflation rates) are associated with low endowment states. But as Kydland and Prescott (1990) and Cooley and Ohanian (1990) have pointed out, the price level in the United States is strongly countercyclical over the postwar period. The predictions of this simple model are also in line with observations reported by Fama (1981) regarding a negative association between stock returns and inflation.

As an extension, this model could be used to interpret an even richer set of correlations that has been reported (for example, Christiano and Eichenbaum, 1992a) in which open market sales (Federal Reserve tightening), high interest rates and subsequent downturns occur. This would simply require price level smoothing on the part of the Fed. For example, suppose that individuals expect a fall in the endowment, and a corresponding rise in the inflation rate (in the absence of any change in monetary policy). If the Fed is interested in ptrsuing price level smoothing, then the Fed would conduct open market sales of " Javanowic (1002) presents a reloted model. the economy, and lower the future price level.
As long as the Fed did not (or was unable to) completely smooth price-level fluctuations, we would observe Fed tightening, higher nominal interest rates, and future output declines. The behavior of the money supply, however, would be entirely endogenous.

This model illustrates how observations that are often interpreted as results of the liqtidity effect can have very different explanations consistent with neoclassical models. While it is unlikely that real shocks account entirely for the observed correlations between nominal interest rates, the money stock and output, given the strong countercyclical behavtor of the price level, it is not at all unreasonable to expect that this mechanism is responsible for at least some of these associations.

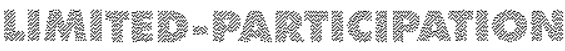

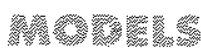

Limited participation (LP) models refer to a class of models, originally proposed. independently by Rotemberg (1984) and Grossman and Weiss (1983), and later developed further by Lucas (1990). ${ }^{6}$ These models provide an alternative interpretation of liqvidity effects. While the sticky-price models discussed above all imply that assets can be priced by using consumption-Euler equations, so that the effects of a monetary disturbance on the time path of consumption determines whether there is a real liquidity effect (as well as how large it is and how long it lasts), limited-participation models provide a means of breaking the link between consumptionEuler equations and real interest rates.

The basic economics of the limitedparticipation theory can be illustrated with a modified version of the Grossman and Weiss model with logarithmic utility. Households are staggered in their visits to financial markets. "Evens" visit financial markets in evennumbered periods and "Odds" visit in oddnumbered periods. It takes time for people to exhaust their money balances, so most people do not participate in financial markets continuously. At any point in time, some are in financial markets and some are out of financial markets. As in cash-in-advance. models, households must use cash to buy goods, but in this model households spend 
their money over two periods rather than one. Also as in cash-in-advance models, each period consists of an asset market (AM) followed by a product market (PM).

A nonstochastic steady-state equilibrium in the Grossman and Weiss model can be described as follows. At period-one asset markets, Odds obtain money for spending during product markets in periods one and two. Then, at period-one product markets, Odds spend a fraction $\phi$ of their money on goods, where $\phi=1 /(1+\beta)$ and $\beta$ is the discount rate, and save the remaining fraction $(1-\phi)$ of their money to spend during the second period. At the same time, in periodone product markets, Evens spend all the money they have left, which is a fraction $\phi$ of the money they had acquired last period (in period-zero asset markets). This will be utility-maximizing behavior for households with separable logarithmic utility and a constant discount rate facing constant nominal prices and opportunities to hold only money and riskless one-period nominal bonds as assets.

Consider a steady state in which Odds and Evens are equally wealthy and have the same consumption profiles (except that they are out of phase by a period). In a steady state with a fixed nominal money supply, $M^{5}$, and with constant endowments of goods, $y=1$, equilibrium nominal prices are constant and total nominal spending on goods each period is $(1 /(2-\phi)) M^{5}$, while $((I-\phi) /(2-\phi)) M^{5}$ money is not spent (because it is carried over to the next period by the households that will not be in asset markets next period).

Starting from this steady state, an unanticipated open market purchase has real effects in the short run: The increase in money must initially be acquired by those households that are in asset markets when it occurs. Suppose the open market operation occurs in an odd period, so odd households initially acquire it all (by selling bonds for money). Because all households spend cash slowly (over two periods), not all the new money is spent at first. The price level rises less-than-proportionally to the money supply. Because Even households (who did not attend financial markets this period) planned already to spend all their money on goods, the increase in the price level reduces their consumption. With constant endowments, equilibrium requires that Odd households consume more this period. However, this increase in consumption by Odd households is temporary; so the anticipated growth rate of the Odd households consumption falls. The consumption-Euler equation for Odd households then implies that the real interest rate over two periods (from now until the Odd household again enters assets markets) falls. Notice, however, that the model breaks the link between real interest rates and the consumption-Euler equation of Even households, so it breaks the link between real interest rates and the path of aggregate consumption.

More precisely, there are equal numbers of Odd and Even households. Odd households choose consumptions, $c_{t}$, and withdrawals of money from financial markets (every other period), $M_{t}$, to maximize

$$
\sum_{t=1}^{\infty} \beta^{t \omega 1} \ln \left(c_{t}^{o}\right)
$$

subject to a sequence of constraints

$$
P_{t} c_{t}^{0}+P_{t+1} c_{t+1}^{o}=M_{t}^{0} \quad \text { for } t \text { odd }
$$

and

(48) $B_{t}^{o}+P_{t-1}=M_{i}^{o}+\frac{B_{i+2}}{\left(1+i_{t, i+2}\right)}+\tau_{t}$ for $t$ odd, and initial conditions on $B_{0}^{\circ}$, the initial level of "bonds" held by the representative Odd household, and $P_{0}$, the period-zero price level; $\tau_{\tau}$ is a lump-sum tax payment that the household must pay (to balance the government budget). Odd household own claims on the endowment streams of firms: They are entitled to the dividends paid by the firm during asset markets at odd-numbered periods (from sales in the product market at the previous even-numbered periods). Firms pay their entire revenue as dividends. The term $M_{1}^{*}$ shows the money that the Odd household acquires during asset markets at date 1 for use in product markets at dates 1 and 2 . This money comes from dividends paid by firms from their sales of goods at date-zero product markets. Notice that utility maximization implies that $P_{t} C_{t}^{o}=\phi M_{t}^{\circ}$ and 
$P_{t+1} c_{t+1}^{o}=(1-\phi) M_{t}^{0}$. Even households solve an analogous maximization problem.

The government collects lump-sum taxes and uses the proceeds as interest on its debt; the representative household has a tax liability equal to the present value of the total government debt. The government may also engage in open market operations. The government's budget constraint is

$$
M_{t}^{5}-M_{i-1}^{s}+\frac{B^{g}}{1+i_{i, t+1}}+\tau_{t}=B_{i}^{g},
$$

which says that the government finances it debt obligations by printing money, or by borrowing from or imposing lump-sum taxes on households currently in asset markets. In the steady state, this budget constraint becomes simply $\tau=(\mathrm{i} /(1+i)) B^{g}$. The initial level of government bonds is given exogenously.

Equilibrium requires a sequence of prices and interest rates so that households maximize utility, and product and asset markets clear:

$$
c_{i}^{0}+c_{t}^{e}=1
$$

and

(51) $M_{t}^{e}=P_{t-1}+M_{t}^{s}-M_{t-1}^{5} \quad$ for $t$ even,

$$
M_{t}^{c}=P_{t-1}+M_{t}^{5}-M_{t-1}^{5} \quad \text { for todd }
$$

The latter conditions require that households in financial markets acquire all the money paid by firms as dividends that period plus any new money printed by the government.

Consider the following sequence of events in a steady-state equilibrium with fixed money supply $M$. In each odd period $t$, the representative Odd household acquires money $(1 /(2-\phi)) M$ at asset markets and then spends $(\phi /(2-\phi)) M$ in product markets, saving $((1-\phi) /(2-\phi)) M$ to spend next period. The representative Even household spends all its remaining money, $((1-\phi) /(2-\phi)) M$, on goods. Total nominal spending on goods is $(1 /(2-\phi)) M$. In each even period, the representative Even household acquires money $(1 /(2-\phi)) M$ at asset markets and then spends $(\phi /(2-\phi)) \mathrm{M}$ in product markets, saving $((1-\phi) /(2-\phi)) M$ to spend next period. The representative Odd household spends all its remaining money, $((1-\phi) /(2-\phi)) M$. Again, total nominal spending on goods is $(1 /(2-\phi)) M$. This sequence repeats in the steady state. Because output is unity, the steady-state nominal price level is $(1 /(2-\phi)) M$.

Now consider a parametric change in the money supply at date 1 , starting from this nonstochastic steady state. The government buys a one-period bond (from the Odd household) with newly printed money. The Odd household now has $(1 /(2-\phi)) M+\Delta M$ dollars and spends $\phi((1 /(2-\phi)) M+\Delta M)$ on goods. The Even household still has $((1-\phi) /(2-\phi)) \mathrm{M}$ dollars to spend. Total nominal spending and the price level are then

$$
\begin{gathered}
\phi\left(\frac{1}{2-\phi} M+\Delta M\right)+\frac{1-\phi}{2-\phi} M \\
\quad=\frac{1}{2-\phi} M+\phi \Delta M .
\end{gathered}
$$

With $\phi \leq 1$, the price level rises but falls short of its new steady-state value of $(1 /(2-\phi))(M+\Delta M)$. This rise in the price level reduces the real consumption of Even households from $1-\phi$ to $((1-\phi) /(2-\phi)) \mathrm{M} /$ $((1 /(2-\phi)) M+\Delta M)$. Equilibrium real consumption of Odd households rises by the amount that Even household consumption falls.

The following period $(t=2)$, Even households acquire all the money that was spent at $t=1$ and spend a fraction $\phi$ of it, so they spend $\phi[(1 /(2-\phi)) M+\phi \Delta M]$. Odd households spend their remaining $(1-\phi)((1 /(2-\phi)) M+\Delta M)$ on goods, so total nominal spending (and the price level) is $(1 /(2-\phi)) M+\left(\phi^{2}+1-\phi\right) \Delta M$. With $1 / 2 \leq \phi \leq 1$, the price level rises at $t=2$ and overshoots its new steady-state level. The price level then falls below its steady-state level at $t=3$ and shows damped oscillations as it approaches its new steady state. (The subsequent adjustment of the price level can be described by the difference equation, $\left.P_{t}=\phi P_{q-1}+(1-\phi) P_{t-2}.\right)$

Equilibrium real interest rates can be computed in this model from consumptionEuler equations. Consumption by Odd households rises at $t=1$ (when the open market purchase occurs), then falls at $t=2$ (as Even households go to asset markets and 
acquire the portion of the new money that Odd households spent at $t=1$ ). The twoperiod change in consumption for Odd households is also negative, as the economy approaches (with two-period oscillations) its new steady state. So the two-period market real interest rate falls at $t=1$, and the implicit one-period real interest tate from the consumption-Euler equations of Odd households also falls. This is the liquidity effect of monetary expansion in the basic limited-participation model. Notice that because consumption of Even households falls at $t=1$, the implicit one-period real interest rate from their consumption-Euler equations rises at $t=1$, but this is not reflected in any market interest rates because these households are not currently participating in asset markets. At $t=2$, the two-period market real interest rate rises above its steady-state level because the two-period change in consumption of Even households is positive. So the liquidity effect in the limited-participation model is necessarily of limited duration: It vanishes (and in fact reverses itseln) when the identity of the participants changes.

The liquidity effect from the limited-participation model results from the temporary change in consumption of the households who have use of a disproportionate share of newly printed money. In the simple model discussed above, these households cannot use this money to finance a permanent increase in consumption. More generally, the increase in money may raise liquidity (in the model above, relax the two-period, cashin-advance constraint) by more than it raises wealth, so households that obtain the additional money may choose an increase in consumption that is (at least partly) temporary. Although in equilibrium other households must then experience a temporary fall in consumption, the limited-participation nature of the model breaks the link between interest rates and the consumption-Euler equations of those households.

\section{Representutive Household Limined- Porticionion (RHIS) Models}

Limited-participation models are complicated because they involve heterogeneity.
Lucas (1990) and Fuerst (1992) developed variations on the limited-participation model that simplify it by using a representative household, thereby elminating wealth-redistribution effects. Their models go further than the heterogenous-agent LP model discussed above by eliminating the connection between real interest rates and any consumption-Euler equation. The models split the representative household into individuals with unique tasks who later pool wealth and consumption. One person in the household purchases goods with money while another participates in financial markets and receives new money transfers. The new money, in the hands of the latter person, cannot immediately reach the former person and is therefore not available for immediate spending in the goods market. As a result, nominal goods prices do not immediately reflect the new money. (With a binding cash-inadvance constraint in the goods market, nominal prices do not depend at all on the size of the current monetary transfer.) In this way, the model generates short-run price stickiness in response to unanticipated increases in the money supply. The new money introduced into the economy enters the loans market as firms must use money to pay inputs. Households work for money they can use to buy goods next period. Because they know that nominal prices will rise next petiod, the nominal reservation wage rises in proportion to that increase in prices. This raises the nominal amount of money the frm must borrow to pay wages. However, because. a disproportionate share of new money is used in this factor market (rather than being spread throughout all markets that require money), the real interest rate falls.

Although the model is simpler than the I.P model in that there is a representative household, its timing and household splits add new complications. We describe here only the setup of a basic RHLP model (readers are referred to the papers by Lucas and Fuerst for discussions of the model's solution and implications). The basic model has several steps. First, households start each period with all the economy's money, while firms will hold all the economy's money at the end of each period. Initially, households divide 
money between buying goods and lending to financial firms: They lend $D_{t}$ dollars to financial firms and keep $M_{t}-D_{t}$ dollars to spend on goods. Second, financial firms receive a lump-sum transfer, $\tau_{1}$, from the government. Third, fmancial firms lend their money, $D_{t}+\tau_{t}$, to goods-producing frrms. Fourth, goods-producing firms use some or all of this cash to pay $w_{i} L_{i}$ for labor services (in a perfectly competitive labor market) because labor services are subject to a cash-in-advance constraint. Fifth, goods-producing firms produce $f\left(k_{i}, z_{t} L_{t}\right)$ goods using this labor and (previously installed) capital; they decide how many goods to install as capital for next period, $I_{t}$, and how many to sell to households in a perfectly competitive environment. Sixth, goods-producing firms sell $f\left(k_{t}, z_{t} L_{t}\right)-I_{t}$ goods to households for $M_{t}-D_{t}$ dollars. Seventh, goods-producing firms repay (with interest) their loans from financial firms: They pay $\left(D_{t}+\tau_{i}\right)\left(1+i_{t}\right)$ to financial firms. Eighth, goods-producing firms pay dividends, $\Pi_{i}$, to households with all their remaining money:

$$
\begin{aligned}
\Pi_{t} & =M_{t}-D_{t}-\left(D_{t}+\tau_{t}\right)\left(1+i_{t}\right) \\
& +D_{t}+\tau_{t}-w_{t} L_{t} .
\end{aligned}
$$

Finally, financial firms pay interest of $\left(1+i_{\ell}\right) D_{t}$ to households on their loans, and dividends to households with all their remaining money, $\left(D_{t}+\tau_{i}\right)\left(1+i_{i}\right)-\left(1+i_{i}\right) D_{i}$. So the total amount of money that financial firms pay to households at this point is $\left(1+i_{i}\right) D_{i}+$ $\left(D_{t}+\tau_{t}\right)\left(1+i_{t}\right)$. After this payment, households have money balances of $M_{t}+\tau_{t}$, which come from four sources: interest on loans to financial frrms; wage income; dividends from goods-producing firms; and dividends from financial firms.

The representative household chooses consumption, labor supply and deposits to maximize expected utility,

$$
E_{t} \sum_{t=0}^{\infty} \beta^{t+1}\left[U\left(c_{t}, 1-L_{t}\right) \mid \operatorname{Inf} o_{t}\right] \text {, }
$$

subject to a sequence of budget constraints:

$$
M_{i+1}=M_{t}+\Pi_{t}+v_{t}+i_{i} D_{t}+w_{r} L_{t}-P_{t} c_{t}
$$

where $\Pi_{t}$ and $v_{t}$ are the nominal dividends paid at the end of period $t$ by goods-producing firms and financial firms, $M_{t}$ is beginning-ofperiod money balances, $i_{t} D_{t}$ is the interest the household earns on its deposits at financial firms, $w_{l} L_{i}$ is labor income, and $P_{t} c_{i}$ is nominal spending on consumption goods. This budget constraint can be rewritten as

$$
\begin{aligned}
M_{t+1} & =M_{t}+\tau_{t} \\
& +P_{t}\left[f\left(k_{t}, z_{t} L_{t}\right)-k_{t+1}-c_{t}\right]
\end{aligned}
$$

where $\tau_{t}$ is the nominal lump-sum transfer of new money to the representative financial firm and $f\left(k_{t}, z_{t} L_{l}\right)-k_{t+1}$ is output of goods minus investment spending by the representative goods-producing frrm. (This formulation assumes 100 percent depreciation of capital each period.) The household is also subject to a sequence of cash-in-advance constraints:

$$
P_{t} c_{t} \leq M_{t}-D_{t} .
$$

Households must choose labor supply and deposits for date $t$ prior to the realization of uncertainty at date $t$, but can choose consumption after the resolution of uncertainty at that date.

The representative competitive goodsproducing firm maximizes

$$
E_{i} \sum_{i=0}^{\infty} \beta^{t+1}\left[\frac{U_{t, i+1}}{P_{t+1}} \pi_{t} \mid \operatorname{Info} o_{t}\right] \text {, }
$$

where $U_{c, t \rightarrow 1}$ is the representative household's marginal utility of consumption at date $t$, $P_{t+1}$ is the price level at date $t+1$, and $I n f_{\mathrm{t}}$ is the firm's information set at date $t$. The firm's production function depends on capital, labor and a productivity shock, $z_{t}$, so production is $f\left(h_{t}, L_{t}, z_{1}\right)$. Nominal profit equals nominal income from sales, $P_{t} f\left(k_{t}, L_{t}, z_{t}\right)$, minus expenditure for investment, $P_{t} k_{t+1}$, minus expenditure for labor, $w_{t} L_{i}$ :

$$
\pi_{t}=P_{i} f\left(k_{t} L_{i}, z_{t}\right)-P_{i} k_{t+1}-w_{t} L_{i} .
$$

The representative financial firm acquires loans (deposits) $D_{t}$ from households by paying interest $i_{t}$, receives a lump-sum 
transfer $\tau_{t}$ from the government, and lends $B_{t}$ to goods-producing firms at the interest rate $i_{t}$. It chooses loans and deposits to maximize

$$
E_{t} \sum_{t=0}^{\infty} \beta^{t+1}\left[\frac{U_{c, t+\varepsilon}}{P_{t+1}} v_{\mathrm{t}} \mid \text { Info }\right]
$$

where its nominal dividends $v_{t}$ are given by

$$
v_{i}=\tau_{t}+i_{i} B_{t}-i_{t} D_{t}
$$

Note that the total amount a financial firm pays to households at the end of a period equals dividends plus interest payments, or $\tau_{t}+i_{i} B_{t}$.

The basic idea of the model above is similar to the timited-participation models of Rotemberg (1984) and Grossman and Weiss (1983). In this model, all households fully participaie in financial markets, but monetary transfers enter through credit markets (in the sense that they go to funancial firms, which then lend the money) and households cannot use this new money to buy consumption goods. This breaks the link between consumption growth and the real interest rate. Although the separation of product and financial markets creates a sluggish response of the nominal price level to a monetary shock, it is the dispersion of markets rather than price stickiness per se that creates the effect of money on real and nominal interest rates in the model.

Limited-participarion models suggest that econometricians can disregard aggregate consumption data when examining the connection between consumption and interest rates implied by the consumption-Euler equation. The models instead impose a different necessary condition relating real interest rates to different intertetupotal marginal rates of substitution. The Grossman and Weiss model related it to the consumption of a subset of consumers, that is, those who are "in financial markets." The RHLP model relates it instead to an intertemporal margin faced by firms.

Several other researchers have extended these kinds of models to deal with other asset-pricing issues. In a recent article, for example, Lynch (1994) develops a non-monetary model in which aggregate consumption data are not connected with asset prices in the usual way because individual consumption decisions are made at finite intervals that are longer than the measurement interval for asset prices (aggregate consumption is related to asset prices indirectly and in a different way, however). (This is reminiscent. of the Grossman-Laroque model of purchases of durable goods, which are made infrequently due to transactions costs). Lynch also assumes individual heterogeneity in that decisions of different individuals are staggered. This assumption ensures that there is no decision interval for which the model can be rewritten in terms of a representative agent; hence, aggregate consumption is not relevant for asset prices. The staggering of decisions makes the model similar to limited-participation models: With two groups of agents, say, Odds and Evens as in the earlier discussion, Evens finance consumption in odd-rumber periods out of previously held assets by selling riskless, zero-transaction-cost assets. Finite intervals for consumption decisions, with. staggered decision periods across households, smooth the aggregate intertemporal marginal rates of substitution and reduce their correlation with asset prices. Lynch studied the implications of this model for the equitypremium/riskless-rate puzzle (with mixed success). (The infrequent decisionmaking might be thotght to be due to the costs of making decisions; Lynch calculates that the total utility loss relative to every-period decisionmaking is about 1 percent of wealth, In Lynch's model, consumption plans are followed through with certainty between decision intervals,

Though limited-participation models of this sort appear to have met with at least some success in asset-pricing issues more generally, heterogeneous-agent limitedparticipation models have not been applied quantitatively to liquidity effects. Like the representative-household limited-participation models, they break the simple link between consumption and interest rates implied by the usual consumption-Euler equation. In contrast to the RHLP model, they do not replace that connection with a similar relation involving frrms. Instead, they place restrictions on movements in interest 
rates and consumption by a subset of the population. This suggests those models would be easier to test (using panel data) than models in which money demand by firms for purchases of inputs plays a major role. It also suggests a possible common model for explaining liquidity effects and resolving other asset-pricing puzzles. We believe additional research along these lines may be useful.

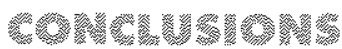

Most economists believe that liquidity effects appear in the data for the U.S. economy, though the size of the effects (if it even exists) is a subject of controversy; due largely to identification problems in statistical work. The theoretical explanation for nominal or real liquidity effects also remains controversial. While many economists interpret liquidity effects as results of sluggish nominal price adjustments, others interpret them as reflecting costs of complete and contintous participation in markets that allow monetary changes to cause redistributions or to channel spending into certain areas (such as increased spending by firms on factors of production). Others suggest that liquidity effects reflect part of the economy's coordination on a particular equilibrium when multiple solutions are possible. Other alternative explanations may appear in future research. Goodfriend (1995) has recently suggested a model in which. imperfectly competitive firms face kinked demand curves and price sluggishness emerges endogenously, creating real effects of monetary policy in which liquidity effects play a role. More generally, the problem of explaining liquidity effects theoretically is part of the broader problem of explaining the effects of monetary policies on a wide range of economic variables. Current explanations may be suggestive, but no definitive model has yet emerged.

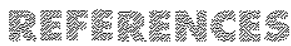

Borno, Robert, and Herschel Grossman. "A Generd Disequilibium Model of Income ond Enployment," The Anericon Economic Review (Warch 1971), pp. $82-93$.
Beaudly, Paul, and Michoel Deveseux. "Monetory Policy and the Real Exchenge Rate in a Price-Setting Model of Monopolistic Competition," Connegie-Rochester Conference Series (forthooming).

Blonchard, Olvier, and Nobethiro Kiyotaki. "Monopulistic Competilion and the Efects of Aggregate Demand, "The American Economic Review (Septembet 3987), pp. 647-66.

Carton, Dennis. "The Theory and the Focts of How Makets Clear: Is

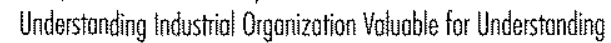
Macroeronemics?" in R. Schmalensee and R.D. Willg, eds., Handbook of industrial Organization. Norththalland, 1989, pp. 909-46.

Cho, Jaig-ok, and Thamas Cooley. "The Business Cyde with Neorninal Controcts," working paper (1990), Uniwersity of Rochester.

Christione, Lowence I. and Martian Eichenboum. "Liquidity Effects and the Monetory Transmission Mecturnism," The American Econonic Review (May 19920), pp. 34653. and "liquidity Effects, Monetary Polly, and the Business Cyce," Notiond Busew of Econemic Research Woking Poper Ho. 4129 (August 1992b).

Cook, Timothy, and Thomas Hahn. "The Effect of Changes in the Federal Funds Rote Target on Warket Interest Rates in the 1970s," Journal of Nonetory Economics (Navenber 1989), pp. 331-51.

Codey, Themas, and Lee E. Ohamian. "Term Stucture Inversion and Real Adwity," wokking paper (1990), University of Rochester.

Fann, Evgene F. "Stork Returns, Reol Activity, linflation and Money" The Americon Economic Review (September 1981), pp. 545-65.

Friedman, Mitton. "Foctors Affecting the Level of interest Rates," Sowings and Residential Finoncing. 1968 Conference Proceedings, U.S. Sovings and toan Lengue, 1968, p. 7.

Fuerst, Thothy. "Liquidity, lonable Funds, and Real Activity, Joumd of honetory Fonomics (Eebroury 1992), p. 3-24.

Goodfriend, Mrevin. "Moderctely Inflotionory Monetery Policy" woking paper (1995), Federd Reserwe Bonk of Richnond.

Grossman, Sanford, and Laurence Weiss. "A Tronsactions-Based Model of the Monetay Transmission Methonism," The Anerican Eronomic Review (lecembe: 1983), pp. 871-80.

Honsen, Gay. "Indivisble Labor and the Business Cycle," Jound of Monetory Economics (November 1985), pp. 309-27.

Jovanowic, Boyan. "In latation and Welfare in the Steady State," Jound of Political Fonomy (Feturuery 1982), pp. 561-77.

King, Robert G. "Motey and Business Gyctes," working joper (1991), University of Rocheste:

Kydand, Fint, and Edword Prescoit. "Business Cycles: Real Facts and a Monetary Myth," Federal Reserve Bolk of Minneopolis Quofterly Review (spring 1990), pp. 3-18.

Luacs, H., RobertE. "liquidity and Interest Rotes," Joumal of Economic Theory (April 1990), pp. 237-64.

"Interest Rotes and Currency Rates in a Two-County Madel," Jounal of Monetary Economics (Novenber 1982), pp. 335.59. 


\section{REVIIW \\ MaY/JUNE 1995}

Lynch, Anthony W. "Stoggered Decision-Making by lindwiduals. Pricing Implications and Empisical Evidence," working peper (1994), University of Chicaga.

Moccet, Abert. "Solving Nonlinear Models by Porameterizing Expeetations," working poper (1990), Feterol Reserve Bank of Minneapolis.

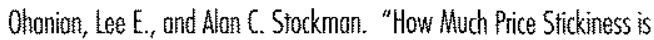
Necessary for Rensonable Liquidity Efferts?" wolking pøper (1994).

Prescott, Edword. "Theory Aheod of Business Cycte Meossurement," ConegieRochester Conference Series on Public Policy (spring 1986), pp. 11-44.

Rotembero, Julia. "A Monetary Equilthrium Model with Transactions Costs," lound of Polfical Econorny (February 1984), pp. 40-58.

Stockmon, Alan C., and Lea E. Ohosion. "The Short-Run Independence of Monetory Policy under Peyged Exchange Rutes," wokking paper (1994), University of Rochesser. 